https://doi.org/10.17816/MAJ191S158-60

\title{
THE CHARACTER OF SYSTEMIC CHANGES IN ADAPTIVE AND INNATE IMMUNE RESPONSE IN PATIENTS WITH MULTIPLE SCLEROSIS
}

\author{
I.I. Andreeva, L.P. Sizyakina, Z.A. Goncharova
}

Rostov State Medical University, Rostov-on-Don

\section{ХАРАКТЕР СИСТЕМНЫХ ИЗМЕНЕНИЙ АДАПТИВНОГО И ВРОЖДЕННОГО ИММУННОГО ОТВЕТА У ПАЦИЕНТОВ С РАССЕЯННЫМ СКЛЕРОЗОМ}

\author{
И.И. Андреева, Л.П. Сизякина, З.А. Гончарова
}

ФГБОУ ВО «Ростовский государственный медицинский университет», Ростов-на-Дону

\begin{abstract}
The article presents the results of a comprehensive analysis of the parameters of innate and adaptive immunity in 85 patients with recurrent remitting multiple sclerosis (MS) with its exacerbation (54 people) and in conditions of persistent clinical remission (31 people). It is shown the signs of autoinflammation and increased reactivity of the T-link of adaptive immunity to be registered not only in exacerbation, but also in remission. The revealed changes determine the pathogenetic basis of MS progression and they should be taken into account when accompanying patients in remission to prevent clinical activation.
\end{abstract}

Keywords: multiple sclerosis; innate immunity; adaptive immunity.

Представлены результаты комплексного анализа параметров врожденного и адаптивного иммунитета у 85 пациентов с рецидивирующе-ремиттирующим рассеянным склерозом (РС) при его обострении (54 человека) и в условиях стойкой клинической ремиссии (31 человек). Показано, что признаки аутовоспаления и повышенной реактивности Т-звена адаптивного иммунитета регистрируются не только в обострении, но и в ремиссию. Выявленные изменения определяют патогенетическую основу прогрессии РС и должны учитываться при сопровождении пациентов в условиях ремиссии для предупреждения клинической активации.

Ключевые слова: рассеянный склероз; врожденный иммунитет; адаптивный иммунитет.

Introduction. Multiple sclerosis (MS) is currently considered as one of the classic examples of clinical manifestation of disorders of the nervous and immune system interaction. Despite numerous studies, the choice of immunological markers of MS prognosis remains unresolved [1, 2]. The aim of the study was to analyze systemic reactions of adaptive and innate immunity factors in MS patients in acute and clinical remission.

Materials and methods. 85 people with recurrent and remitting course of MS have been examined. The diagnosis was made on the basis of MC Donald criteria [3]. 54 patients were examined during the exacerbation of the disease, 31 - in the stage of persistent clinical remission. Phenotypic analysis of lymphocytes was performed on "FC 500" cytofluorometer. Cytolytic activity of NK was assessed by the ability to lyse antigen mediated Fcrr type III and was expressed by the indicator of absolute cytotoxic activity (CTA). Serum levels of TNF- $\alpha$, IL-4, IFN- $\gamma$ were determined by IFA. The control group consisted of 10 blood donors. Mathematical data processing was performed using the program Statistica 7.0.

Results and discussion. The results of evaluation of the immune system parameters in patients with MS in the acute stage indicate an increase in the absolute number of T-lymphocytes and
T-cells expressing markers of early (CD25) and late (HLA DR) activation with an increase of stimulation index value of RBTL on T-mitogen. $\mathrm{CD} 4^{+}$-subpopulation is characterized by a decrease in the circulating proportion of $\mathrm{CD}^{+}$ $\mathrm{CD} 25^{+} \mathrm{Foxp}^{+}$-Treg, with the prevalence of Th1-immune processes, which reflect an increase in the ratio of $\mathrm{Th} 1 / \mathrm{Th} 2$ (sp) and Th1/Th2(st). Innate immunity link characterizes the increase in metabolic activity of phagocytic cells, activation of maturation of NK and their cytolytic activity, increased expression of Toll-like receptors on monocytes. Changes in the serum cytokine spectrum are manifested by an increase in the content of TNF- $\alpha$ and a change in the ratio of IFN- $\gamma /$ IL- 4 to the activation of cell-mediated processes (Table 1). Remission of MS is associated with a decrease in the absolute number of mature $\mathrm{CD}^{+}$-cells with increased expression of CD25 R. Proliferation of T-lymphosytes exceeds the control values. The amount of Treg is within the control, as well as the number of monocytes expressing 4 and 9 TLR, the serum content of TNF- $\alpha$. At the same time, serum IFN- $\gamma$ level and IFN- $\gamma /$ IL-4 ratio exceeds the control parameters. In the conditions of remission of MS, a decrease in the number of NK was revealed, but their functional activity, as well as spontaneous metabolic activity 
Table 1

Cellular and humoral indicators of innate and adaptive immune response in exacerbation and remission of multiple sclerosis

\begin{tabular}{|l|c|c|c|}
\hline \multicolumn{1}{|c|}{ Indicators } & Exacerbation & Remission & Control \\
\hline $\mathrm{CD}^{+}, 10^{9} /$ л & $1.91 \pm 0.06^{*}$ & $0.81 \pm 0.03^{*}$ & $1.22 \pm 0.03$ \\
\hline $\mathrm{CD}^{+} \mathrm{CD} 25^{+}, \%$ & $2.77 \pm 0.24^{*}$ & $2.79 \pm 0.12^{*}$ & $2.15 \pm 0.17$ \\
\hline $\mathrm{CD}^{+} \mathrm{HLA} \mathrm{DR}^{+}, \%$ & $9.49 \pm 0.51^{*}$ & $7.66 \pm 0.44$ & $8.04 \pm 0.14$ \\
\hline RBTL & $72.12 \pm 1.97^{*}$ & $73.14 \pm 4.91^{*}$ & $63.60 \pm 0.87$ \\
\hline Treg/CD4${ }^{+}, \%$ & $0.97 \pm 0.03^{*}$ & $1.62 \pm 0.2$ & $3.25 \pm 1.6$ \\
\hline Th1/Th2sp & $6.16 \pm 0.52^{*}$ & $3.41 \pm 0.26^{*}$ & $2.32 \pm 0.04$ \\
\hline Th1/Th2st & $7.44 \pm 0.50^{*}$ & $4.07 \pm 0.15^{*}$ & $2.98 \pm 0.10$ \\
\hline NBTsp & $105.45 \pm 7.34^{*}$ & $108.70 \pm 7.92^{*}$ & $90.12 \pm 1.01$ \\
\hline CD16 ${ }^{+}, 10^{9} / 1$ & $0.40 \pm 0.07^{*}$ & $0.14 \pm 0.02^{*}$ & $0.21 \pm 0.01$ \\
\hline $\mathrm{CTA}, \mathrm{y} . \mathrm{e}$. & $9.65 \pm 0.56^{*}$ & $6.59 \pm 0.89^{*}$ & $3.54 \pm 0.12$ \\
\hline $\mathrm{CD} 14^{+} \mathrm{CD} 284^{+}, \%$ & $39.2 \pm 14.9^{*}$ & $19.5 \pm 5.3$ & $20.0 \pm 4.0$ \\
\hline $\mathrm{CD} 14^{+} \mathrm{CD} 289^{+}, \%$ & $23.5 \pm 4.1^{*}$ & $5.2 \pm 2.2$ & $3.0 \pm 1.0$ \\
\hline $\mathrm{TNF}-\alpha, \mathrm{pg} / \mathrm{ml}$ & $9.48 \pm 0.96^{*}$ & $1.46 \pm 0.11$ & $1.14 \pm 0.16$ \\
\hline $\mathrm{K} \mathrm{IFN-} \gamma / \mathrm{IL}-4$ & $45.14 \pm 8.72^{*}$ & $11.75 \pm 5.23^{*}$ & $3.3 \pm 1.5$ \\
\hline
\end{tabular}

N o te. ${ }^{*} p<0.05-$ statistical validity of indicator differences in comparison with control.

of neutrophils still remain higher than in healthy ones (Table 1).

Conclusion. Thus, the exacerbation of MS is associated with increased activation and proliferative potential of T-lymphocytes, inhibition of immunosuppression, increased effector reactions of innate and adaptive variants of the immune response. In remission, the readiness to perceive activation stimuli and proliferative ability of $\mathrm{T}$-cells, the effector activity of the cellular link of the innate immunity are not completely restored and remain elevated, the cytokine dysregulation of the immune response is not stabilized. These signs are evidence of the role of autoimmunity and autoinflammation in the pathogenesis of the disease, and complete stabilization of indicators of the functioning of the immune system lack in remission indicates the need for autoimmune process correction and beyond its active clinical manifestation.

\section{References}

1. Christophi GP, Gruber RC, Panos M, et al. Interleukin-33 upregulation in peripheral leukocytes and CNS of multiple sclerosis patients. Clin. Immunol. 2012;142(3):308-319.

2. Andreeva II, Sizyakina LP, Goncharova ZA. Inversion of the homeostatic properties of the immune system in multiple sclerosis. Medical Bulletin of the South of Russia. 2016;2:23-27.

3. Martinez NE, Karlsson F, Sato F, et al. Protective and Detrimental Roles for Regulatory T Cells in a Viral Model for Multiple Sclerosis. Brain Pathol. 2014;24(5):436-451.

4. Mc Donald WI, Compston A, Edan G, et al. Recommended Diagnostic Criteria for Multiple Sclerosis: Guidelines from the International Panel on the Diagnosis of Multiple Sclerosis. Ann Neurol. 2001;50:121-127. 